\title{
The Church of St. Stephen
}

\section{K. Spyridonidis}

To cite this article: C. K. Spyridonidis (1907) The Church of St. Stephen, Palestine Exploration Quarterly, 39:2, 137-139, DOI: 10.1179/peq.1907.39.2.137

To link to this article: http://dx.doi.org/10.1179/peq.1907.39.2.137

曲 Published online: 19 Jul 2013.

Submit your article to this journal

LII Article views: 4

Q View related articles $\sqsubset$ 
kill one they consider equal in importance to the man they have lost. In the same way, should a woman kill a man, a man of her family or tribe, and not she, is made to pay: the penalty of blood.

In some cases, so Sheikh Suleiman el-Awamra told me, the feud may be brought to an end, after one life has been taken in expiation of the original murder, by the avenger, whoever he may be, dipping his handkerchief in the blood of the man he has killed and taking it to the family as a token that there the matter ends-a life having been taken for a life. It rests with the others to accept or refusethe reconciliation.

The great object of all tribes is to keep up their fighting strength on an equality with that of their neighbours, which explains why not only must the penalty to be exacted be estimated by the number, but also by the importance of the men lost on either side.

A woman or child could only be killed unintentionally, and the matter would be settled by the payment of a heavy fine. I have only heard of one instance where several were killed by raiders, and that was when they fell upon an encampment at night while the dafiieh was being danced. The raiders fired indiscriminately into the group, and four or five women were shot. Such things may happen now and then, but they are rare, and Bedouin feeling is strongly against either women or children being touched.

(To be continued.)

\section{THE CHURCH OF ST. STEPHEN.}

\section{By C. K. SpYridonidis, Jerusalem.}

BEFORE we arrive at Gethsemane, just at the place where we learn, by tradition, that Stephen was stoned, there is a field which some years ago was bought by the Rev. Epthimios, the treasurer of the Holy Sepulchre. The Mohammedans say that the blood of the sacrifices offered by the Jews in the temple flowed through this. place. The area of it must be about three thousand square metres. Before I commenced constructing I heard from a Mohammedan that this place must be a very interesting one, as there were found: 

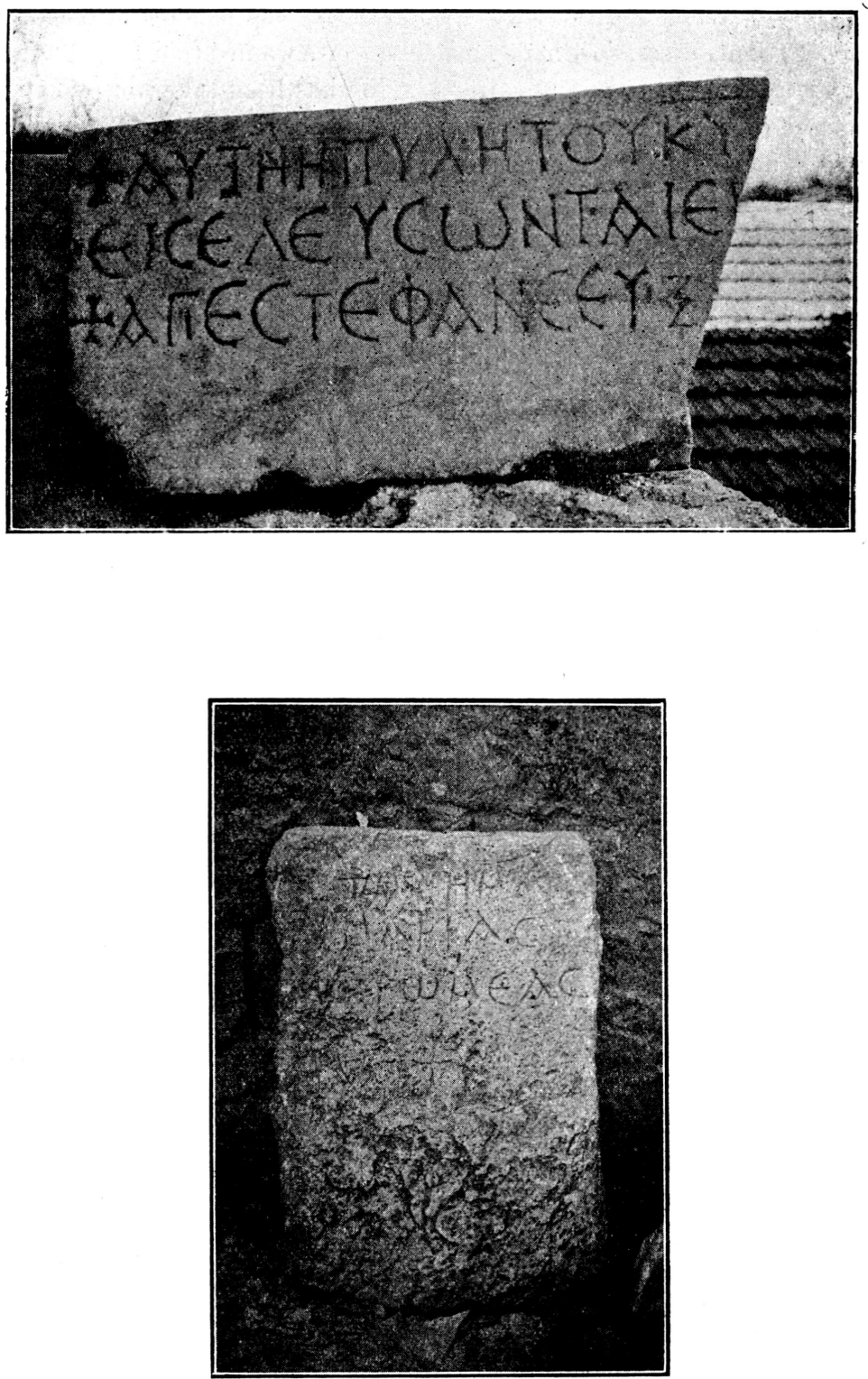
in it many large chiselled stones. Through it passes the general sewer of the city. In levelling this field I found different things, but at present cannot speak about them; it must suffice to refer to two inscriptions found, one on a piece of marble, which says :

\section{A AYTH H TYAH TOY KYPIOY EICEAEYCWNTAI $\in N$ AYTH}

\section{* ArIE CTEQANE EY}

The second one was found on another large stone and reads :

\section{+ MNHMA MAPIAC PWMEAC}

The inscription of the marble has been taken from Ps. cxv, 20. The marble is somewhat broken at the edges, and I think that after the Greek work AYTH comes the word $\triangle I K A I O I$, and after CTEФANE EYE, AI YחEP HMWN. The characters of the first inscription lead us to believe that they were written in the fourth century. Usually the above inscription is found on the door-sills of Greek churches.

The dimensions of the marble are $17 \frac{3}{4}$ in. $\times 9 \frac{1}{2}$ in., and of the stone $24 \frac{3}{8}$ in. $\times 37 \frac{3}{8}$ in.

Further above where these slabs were lying there was found a well, which is carefully constructed and appears to have been newly plastered, but is nearly filled with earth and stones.

At present we have not fully completed the excavations, so cannot give further information.

The first inscription, according to the Greek orthography, has one mistake which I indicate by a line:

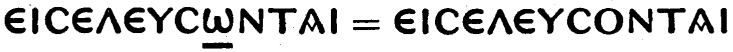

The second one has another one which I also note:

$$
P W M E A C=P W M A I A C
$$

The inscriptions seem to be sufficient evidence that this is the exact spot where stood St. Stephen's original church. 